\title{
The theoretical-empirical technique of hydrocarbons prediction in wells sections. New aspects
}

\author{
L. Skakalska ${ }^{1}$, A. Nazarevych ${ }^{1}$, V. Kosarchyn ${ }^{2}, 2021$ \\ ${ }^{1}$ Carpathian Branch of Subbotin Institute of Geophysics \\ of the National Academy of Science of Ukraine, Lviv, Ukraine \\ ${ }^{2}$ Lviv National Agrarian University, Lviv, Ukraine \\ Received 13 July 2020
}

\begin{abstract}
We present the developed theoretical-empirical technique for predicting of rocks' oiland-gas bearing in wells sections according to acoustic logging (AL) and core research (CR) and its variants by using data of other loggings and also the results of testing them on wells sections data in the Western oil and gas bearing region of Ukraine (WOGR). The mathematical apparatus of the created technique is based on a mathematical model of solid porous rock, empirical relationships between elastic and reservoir characteristics of rocks and acoustic logging data for specific studied wells. The key parameter in the calculations is the rock compressibility. Determination of the porosity of rocks and prediction of the type of pore filler (water, oil, gas) is implemented by comparing the results of calculating the velocities using theoretical and constructed empirical relationships with the actual data of the $\mathrm{AL}$, by the parameter of compressibility of rocks, by the density of the pore filler fluid.

Additional versions of the technique have been developed based on correlation dependences and data from other logging methods - gamma-ray logging (GL), electric logging (EL/SP), offset method and seismic logging (SL). They are used in case of absence of AL data for the studied wells or for the intervals of their sections, and also for improving the reliability of prediction the oil and gas content of these sections. The software for the implementation of the technique was developed in Fortran, C\# and Excel software environments.

The technique was tested on the data of wells of a number of structures of the WOGR of Ukraine (Lishchyns'ka, Buchats'ka, Ludyns'ka, Zaluzhans'ka, Zarichnyans'ka and Nyklovyts'ka).The technique ensures reliable prediction of petrophysical characteristics, porosity and oil-gas-water saturation of rock layers of different thicknesses (including thin layers - from $0.1-0.2 \mathrm{~m}$ ) in well sections. For this, in addition to the data of the general parametric base of the WOGR reservoir rocks, the specially constructed refined empirical relations for various specific types and subtypes of the WOGR reservoir rocks are used, they are based on the results of analysis of petrophysical characteristics of those rocks.

Key words: theoretical-empirical predictivetechnique, oil-gas-water-saturation of rock, wellsection, acoustic logging, core research, reservoir rocks, porosity, compressibility, empirical relations, Western oil-gas bearing region of Ukraine.
\end{abstract}

Searching for new hydrocarbon deposits is caused by the exhaustion of shallow and simple objects. Therefore, predicting the oil and gas content in the well sections is an actual task of exploration geophysics. It is important to improve the efficiency of such predicting for reliable detection of oil and gas fields in complicated geological conditions.

For this, we have developed the theoretical and empirical techniques for predicting the type of fluid saturation of rocks in well sections using acoustic logging (AL) and core research (CR). Variants of the techniques are developed [Skakalska, 2014a,b; Skakalska, Nazarevych, 2014, 2015a,b, 2016a,b, 2018; Skakalska et al., 2017] using data of other loggings and the corresponding correlation relations. 
We present the results of the technique approbation in well sections in the Western oil and gas region of Ukraine (WOGR). For improving the efficiency of predicting the oil and gas content of the well sections, we also carry out the detailed studies of correlations of the parameters of compressibility, porosity and pressure for the general parametric base of the WOGR and for a number of specific types and subtypes of rock collectors and various fluids - fillers of their pores (water, oil, gas).

In particular, we present the study of multiplicative component of correlation formula of influence the pressure and porosity on the compressibility and velocity of elastic waves in rock collectors. Based on such refined relations, we developed a method for identification of the rock type in each layer of the well section according to the obtained by predictive technique values of compressibility of the solid phase of the rock.

The basic variant of the theoretical-empirical predictive technique. The mathematical apparatus of the technique. The developed technique is created as a complex mathematical apparatus based on an adequate mathematical model of solid porous rocks [Petkevych, Verbytskiy, 1970; Verbytskiy, 1977; Verbytskyy et al., 1985], empirical relations between elastic and collector characteristics of rocks and acoustic log data of particular explored wells [Skakalska, 2014a,b; Skakalska, Nazarevych, 2014, 2015a,b, 2016a,b, 2018; Skakalska et al., 2017]. The parameter of compressibility of rocks $\beta$ is basic for the calculation on the technique.

We use such physical-mathematical models. In the model for well section (Fig. 1, b), the actual rocks are divided into symbolically thin layers according to the step inside the well depth of the data of the interval time for AL. On the physical and mathematical model of the rock (Fig. 1, c), the rock in each layer is represented as a nonlinear-elastic,
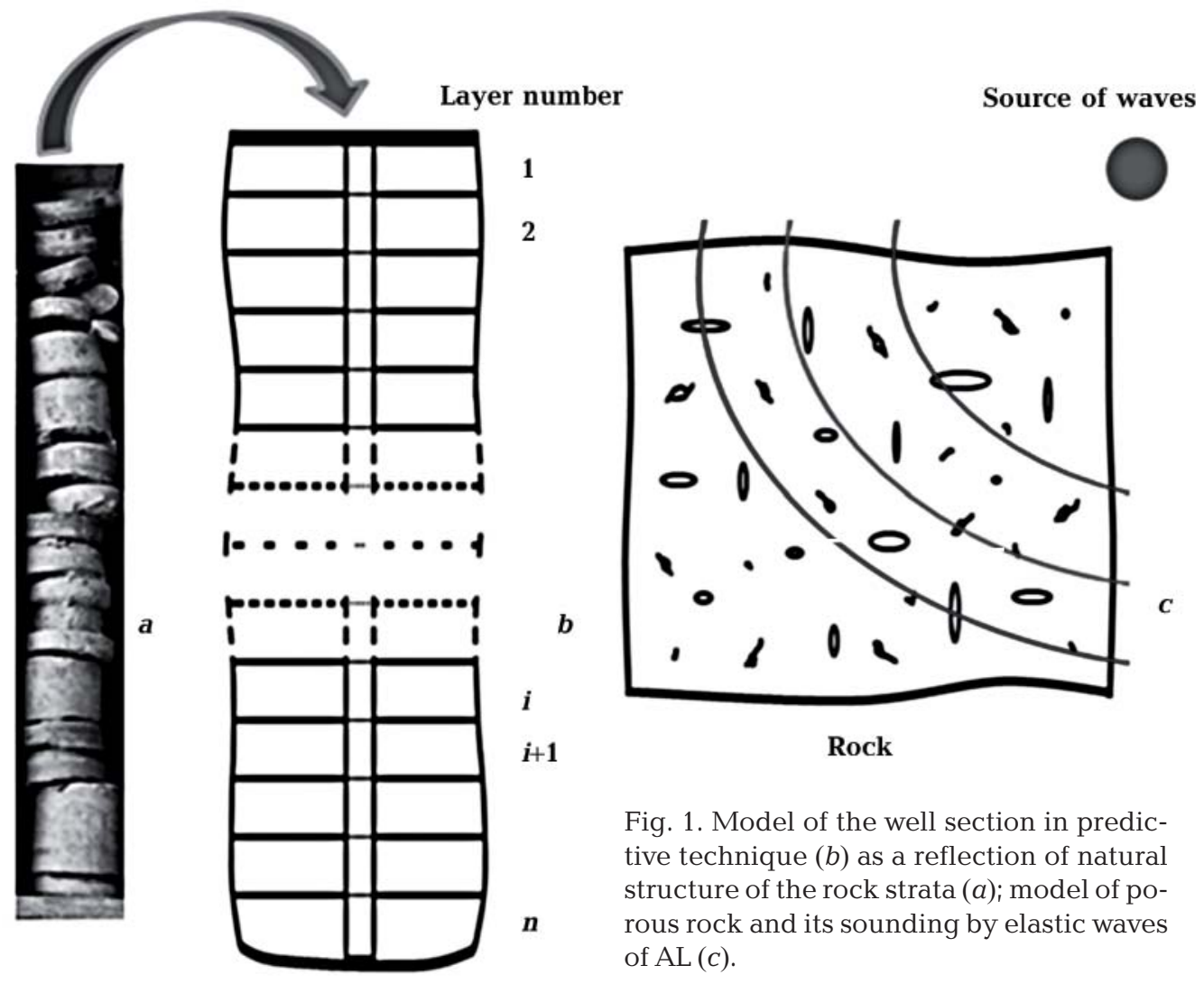

Fig. 1. Model of the well section in predictive technique $(b)$ as a reflection of natural structure of the rock strata $(a)$; model of porous rock and its sounding by elastic waves of $\mathrm{AL}(c)$. 
micro-inhomogeneous cracked-porous solid geological environment with an arbitrary number of ellipsoidal inclusions of various sizes and forms, filled with liquid or gas, whose characteristics, respectively, influence on the propagation of elastic waves in it.

Mathematically, such a rocks model is described by a system of theoretical and empirical relations. They accumulate: J. Eshelby's research on the description of the average elastic constants of a solid medium filled with spherical inclusions; the formulas of G. Walsh for the environment with hollow inclusions; the relationships between the elastic modules of variously saturated rocks developed for this model by F. Gassmann and their clarifications by J. Frenkel and M. Biot. Later G. Petkevych, T. Verbyts'kyy and O. Fedoryshyn supplemented and expanded them for the description of elastic characteristics of any type of the rock with an arbitrary number and size of porous and cracked inclusions [Petkevych, Verbytskiy, 1970; Verbytskiy, 1977; Verbytskiy et al., 1985].

The theoretical relations were obtained for the calculation of elastic parameters of each layer (Fig. 1, a) of the well section [Skakalska, 2014a,b; Skakalska, Nazarevych, 2014, 2015b, 2016a,b, 2018; Skakalska et al., 2017]:

$$
\begin{gathered}
\mu_{1}^{g}=\frac{\rho_{i 1}^{g} \mu_{1}^{w}}{\rho_{1}^{w}} ; \\
\mu_{i}^{g}=1 /\left[\frac{1}{\mu_{i-1}^{g}}-\frac{5-v^{T}}{3} \frac{15\left(\mu_{i}^{w}-\mu_{i-1}^{w}\right)+4 \mu_{i-1}^{w} \mu_{i}^{w}\left(\beta_{i}^{w}-\beta_{i-1}^{w}\right)}{15 \mu_{i-1}^{w} \mu_{i}^{w}}\right] ; i=2, \ldots, n ; \\
\beta_{k}^{g}=\beta_{k+1}^{g}+\frac{15}{4} \frac{\mu_{i+1}^{g}-\mu_{i}^{g}}{\mu_{i+1}^{g} \mu_{i}^{g}} \frac{2-v_{k}^{T}}{5-v_{k}^{T}} ; k=\overline{n-1,1} ; k=n-i+1 ; \\
\beta_{n}^{g}=\frac{3 \rho_{i}^{w}}{\rho_{i n}^{g}\left(3 / \beta_{n}^{w}+4 \mu_{n}^{w}\right)-4 \mu_{n}^{g} \rho_{i n}^{w}} ;
\end{gathered}
$$

where $\rho_{i 1}^{g}, \rho_{1}^{w}, \rho_{i n}^{g} \rho_{i n}^{w}$ - bulk density of rocks in a layer (for various pore filler), $\mathrm{kg} / \mathrm{m}^{3} ; v_{k}^{T}$ — Poisson's ratio of the solid matrix of the rock layer; $\beta_{i-1}^{g}, \beta_{i}^{g}, \beta_{i-1}^{w}, \beta_{i}^{w}$ - compressibility and $\mu_{i-1}^{g}, \mu_{i}^{g}, \mu_{i-1}^{w}, \mu_{i}^{w}$ - shear modulus of the $i-1$-th and $i$-th layer of a dry or fluid-saturated rock, $\beta_{k+1}^{g}, \beta_{k}^{g}, \beta_{k+1}^{w}, \beta_{k}^{w}$ and $\mu_{k+1}^{g}, \mu_{k}^{g}, \mu_{k+1}^{w}, \mu_{k}^{w}$ - similar for $k$-th and $k+1$-th layers; $i$ - the number of the studied layer in the section (see Fig. $1, a$ ) for the sequential calculation from the upper layer to the lower one; $k$ - the number of the studied layer in the section with the successive calculation from the lower layer to the upper one.

The condition (Eq. (1)) of the equality of transverse elastic waves velocities (regardless of the type of the fluid - the pore filler) in an unloaded medium - of the first layer rock, on which the cut split is presented by Eq. (1). Eq. (2) is a recurrent expression and needs the initial values obtained from Eq. (1).

The formula (Eq. (4)) is derived from the condition of equality of the velocities of longitudinal waves in the loaded dry and saturated by a liquid when the pores are closed $(\phi=0 \%)$. It is used to calculate the effective values of compressibility by formula (Eq. (3)) in the rest of the section layers. Thus, formulas (Eq. (1)) and (Eq. (4)) impose initial (boundary) conditions for calculating the values of the share modulus and compressibility in the calculation from the first layer (Eq. (2)), and from the deepest one respectively, (Eq.(3)).

Note that conditions (Eq. (1)) and (Eq. (4)) for the calculation for a particular well may include correction factors that take into account the difference in the operating pressure in layers 1 and $n$ at the minimum and the maximum of the studied depths.

The empirical relations in the system of equations of the technique reflect the results of the statistical analysis of the parametric base (specific experimental data of the core research) of 
the interconnection of various physical properties of real rocks as a multiparameter geological environment. These properties extrapolate the behaviour of the main investigated parameters of the rocks of the respective field, field region, taking into account the influence of pressure, layering, microporosity, the skeletal structure and porous space, clayiness and other factors:

$$
\beta^{g(w)}(\delta, \phi)=\beta_{0} f^{g(w)}(p, \phi) ;
$$

where $\beta_{0}=1 \times 10^{-11} \mathrm{~Pa}^{-1}$ — the basic value for the rocks compressibility (coefficient for bringing dimensionless data of table 1 (see below) to real values); $f^{g(w)}(p, \phi)$ - empirical relations of compressibility $\beta$, pressure $p$ and porosity $\phi$ for variably saturated rocks, determined by statistical studies.

Ta b l e 1. The experimental values of compressibility $\beta_{\text {exp }}$ for different-porous water-saturated reservoirs of the WOGR with different values of operating pressure $p$ (according to UkrSGRI)*

\begin{tabular}{|c|c|c|c|c|c|c|c|c|c|}
\hline & & 1 & 2 & 3 & 4 & 5 & 6 & 7 & 8 \\
\hline & $j=\varphi_{j}, \%$ & 0.1 & 1.0 & 2.5 & 5.0 & 10.0 & 20.0 & 40.0 & 80.0 \\
\hline 1 & 0.40 & 1.85 & 1.80 & 1.80 & 1.75 & 1,70 & 1,70 & 1,70 & 1,65 \\
\hline 2 & 2.10 & 1.75 & 1.70 & 1.65 & 1.60 & 1.60 & 1.60 & 1.60 & 1.60 \\
\hline 3 & 3.50 & 2.95 & 3.05 & 3.05 & 3.00 & 2.95 & 2.85 & 1.80 & 2.75 \\
\hline 4 & 3.60 & 2.60 & 2.85 & 2.90 & 2.55 & 2.35 & 2.05 & 1.90 & 1.85 \\
\hline 5 & 3.90 & 2.70 & 2.85 & 2.95 & 2.50 & 2.45 & 2.25 & 2.05 & 2.00 \\
\hline 6 & 5.40 & 3.25 & 3.05 & 2.90 & 2.75 & 2.50 & 2.35 & 2.15 & 1.95 \\
\hline 7 & 9.00 & 6.40 & 5.65 & 5.15 & 4.95 & 4.25 & 3.85 & 3.75 & 2.75 \\
\hline 8 & 12.20 & 5.85 & 5.30 & 5.40 & 4.75 & 4.00 & 3.35 & 3.00 & 2.75 \\
\hline 9 & 14.50 & 5.60 & 5.30 & 5.60 & 4.15 & 3.60 & 3.20 & 3.10 & 3.05 \\
\hline 10 & 15.40 & 5.35 & 5.80 & 5.75 & 4.20 & 3.70 & 3.35 & 3.20 & 3.25 \\
\hline 11 & 17.40 & 9.40 & 8.05 & 7.25 & 6.30 & 5.55 & 4.40 & 3.85 & 3.80 \\
\hline 12 & 18.30 & 9.35 & 8.45 & 7.15 & 6.40 & 5.20 & 4.45 & 4.20 & 4.15 \\
\hline 13 & 19.10 & 10.70 & 10.20 & 9.50 & 7.15 & 5.75 & 4.95 & 4.65 & 4.60 \\
\hline 14 & 19.40 & 8.50 & 8.40 & 6.35 & 5.75 & 5.30 & 4.40 & 4.35 & 4.55 \\
\hline 15 & 22.40 & 10.00 & 8.70 & 7.30 & 6.40 & 5.60 & 4.85 & 4.50 & 4.25 \\
\hline
\end{tabular}

Note: * — in the table values $\beta_{\text {exp }}$ are normalized.

Based on the data of the parametric base and core research for such types/subtypes of rocks (see below), we obtained the appropriate sets of input parameters and characteristics for a specified prediction of the oil and gas content in wells in practical application of the technique for specific intervals of the section with a certain type/subtype of rocks. The appropriate sets of input parameters and characteristics are used for a specified prediction of the oil-gas content in wells for particular section intervals with a certain type/subtype of rocks.

The type of the pore filler determining. According to the empirical relations (Eq. (5)) the values of elastic parameters compressibility $\beta_{i}$ and share modulus $\mu_{i}$ for various possible types of pore fillers are calculated taking into account the theoretical relations (Eq. (1) - (4)). Next, the corresponding velocities of elastic waves $V_{s i}{ }^{g(w)}, V_{p i}{ }^{g(w)}$ are calculated, thus linking the technique calculations with the data of AL: 


$$
V_{S i}^{g(w)}=\sqrt{\frac{\mu_{i}^{g(w)}}{\rho_{i}^{g(w)}}} ; V_{P i}^{g(w)}=\sqrt{\frac{3 / \beta_{i}^{g(w)}+4 \mu_{i}^{g(w)}}{3 \rho_{i}^{g(w)}}},
$$

where: $\rho_{i}^{g(w)}$ - is the density of gas (liquid)-filled rocks of the corresponding layer.

The type of the pore filler is determined by comparing the calculated velocity of longitudinal waves (for different variants of the types of fluids - pore fillers) and the data of $A L$, with the definition of the nearest to the experimental velocity. Due to this criterion, the type of the fluid is predicted, in accordance with the condition of the minimum of functional $F$ :

$$
F=\min _{\phi_{j \min } \leq \phi_{j} \leq \phi_{\max }}\left\{F_{1}, F_{2}, F_{3}, F_{4}\right\}, i=\overline{1, n}
$$

where:

$$
\begin{gathered}
F_{1}=\left|\sqrt{\frac{1}{\rho_{1}^{T} \beta_{1}^{g}}+\frac{4}{3} \frac{\mu_{1}^{w}}{\rho_{o 1}^{\prime}}}-V_{1}^{A L}\right|, i=1 ; \\
F_{2}=\left\{\left\{\left[\left(1-\phi_{j}\right) \rho^{T}\left(3 / \beta_{n-k+1}^{w}+4 \mu_{i}^{w}\right)-4 \mu_{i}^{g} \rho_{i}^{w}\right] \times\right.\right. \\
\left.\times \frac{\left[\frac{1}{\mu_{i-1}^{g}}-\frac{5-v_{i}^{T}}{3} \frac{15\left(\mu_{i}^{w}-\mu_{i-1}^{w}\right)+4 \mu_{i-1}^{w} \mu_{i}^{w}\left(\beta_{n-k+2}^{w}-\beta_{n-k+1}^{w}\right)}{15 \mu_{i-1}^{w} \mu_{i}^{w}}\right]}{3\left(1-\phi_{j}\right) \rho_{i}^{T} \rho_{i}^{w}}+\frac{4 \rho_{i}^{w}}{3\left(1-\phi_{j}\right) \rho_{i}^{T} \rho_{i}^{w}}\right\}^{\frac{1}{2}}-V_{i}^{i L} \mid, \\
F_{3}=\left|V_{p n}^{w}-V_{n}^{i L}\right|, i=n ; \phi=0 ; p \geq 80 \mathrm{M \Pi a} ; F_{4}=\left|\sqrt{\left(3 / \beta_{i}^{w}+4 \mu_{i}^{w}\right) / 3 \rho_{o i}^{\prime}}-V_{i}^{i L}\right|, i=\overline{1, n} .
\end{gathered}
$$

$F_{1}, \ldots, F_{4}$-modules of deviations of the calculated velocities of longitudinal waves for variously saturated rocks from the values obtained according to AL for each of the studied layers (the rest of the notation - see formulas (Eq. (1) - (4)) and in the text).

Using an adequate mathematical model, the prognostic technique along with the determination of porosity and the prediction of the type of a pore filler gives an opportunity to obtain a complete description of the elastic and collector characteristics of the rocks in each section to determine the modulus of compressibility $(\beta)$, shear $(\mu)$, Jung $(E)$, volume compression $(K)$, Poisson coefficients $(v)$, velocity of elastic waves $\left(V_{S}, V_{P}\right), V_{S}\left(V_{P}\right.$ parameter, density $(\rho)$, pressure $(p)$ according to AL.

The parametric base and empirical relations for the WOGR. A parametric base is necessary for predicting by our theoretical and empirical technique of construction of the necessary empirical ratios. There are examples of prediction calculations below, with using such bases (Table 1) obtained from the core research data.

Since it is difficult to obtain the values of rock compressibility, we propose a way of obtaining them by the results of the measurements of elastic waves velocities. Consequently, for a reliable prediction for a particular well with a specific composition of rocks, the data are calculated by specially derived formulas based on the mathematical model. These data are calculated by the values of volumetric waves velocities obtained from the core and well research.

For the explanation of symbols see formulas (Eq. (1) - (4)) and in the text. 


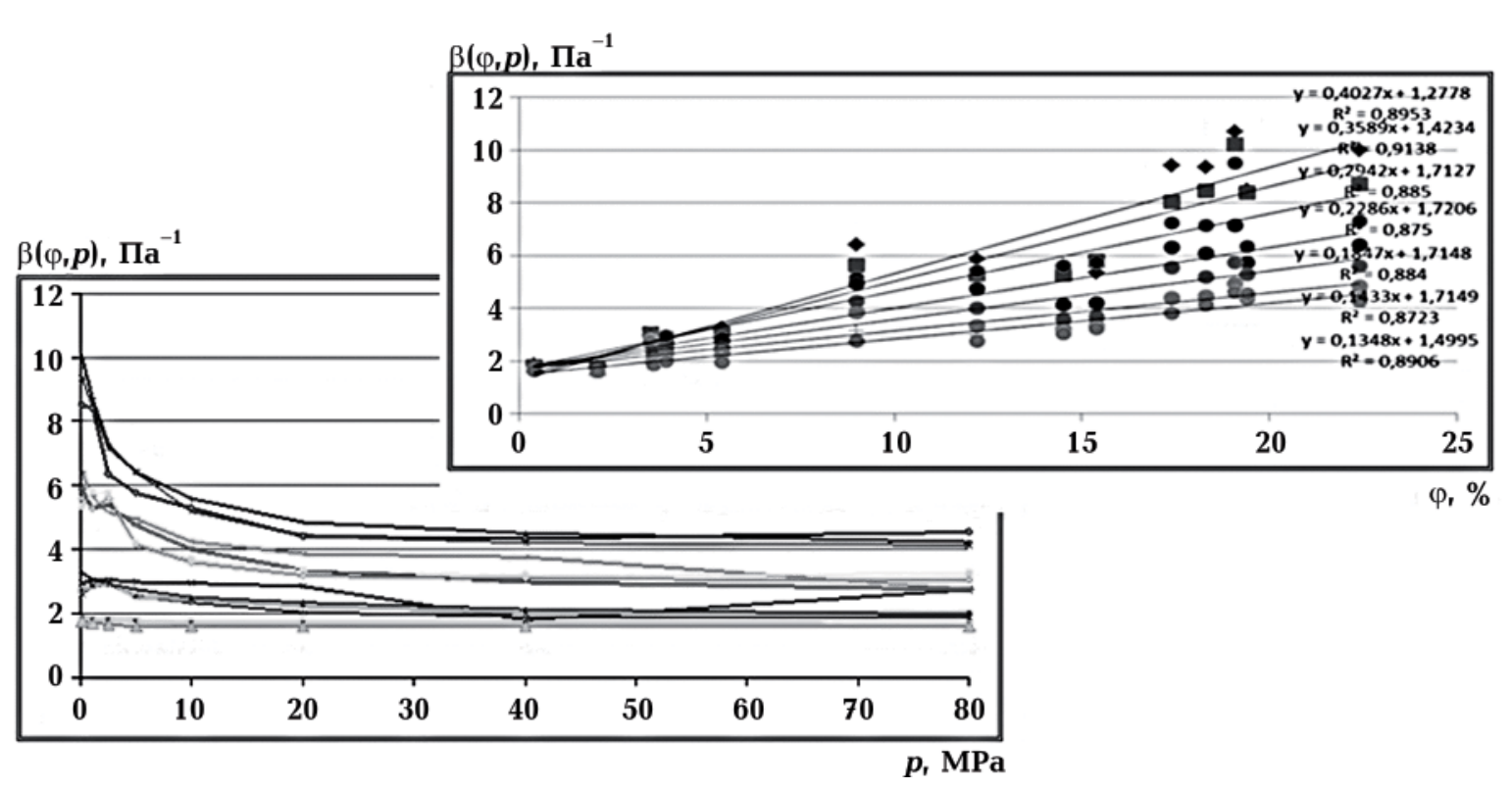

Fig. 2. Compressibility vs. pressure (left bottom) and porosity (right top) for the parametric base of the WOGR (see Table 1).

$$
\begin{gathered}
\beta_{k-1}^{g}=\beta_{k}^{g}+\frac{2\left(V_{S k-1}^{T}\right)^{2}-\left(V_{P k-1}^{T}\right)^{2}}{6\left[\left(V_{S k-1}^{T}\right)^{2}-\left(V_{P k-1}^{T}\right)^{2}\right]}\left[\frac{15}{4}\left(\frac{\left(V_{S k}^{T}\right)^{2} \rho_{k}^{T}-\left(V_{S k-1}^{T}\right)^{2} \rho_{k-1}^{T}}{\left(V_{S k-1}^{T} V_{k}^{T}\right)^{2} \rho_{k-1}^{T} \rho_{k}^{T}}\right)-\right. \\
-\frac{\rho_{o k}^{w}\left[\left(V_{P k}^{w}\right)^{2}-\frac{4}{3}\left(V_{S k}^{w}\right)^{2}\right]-\rho_{o k-1}^{w}\left[\left(V_{P k-1}^{w}\right)^{2}-\frac{4}{3}\left(V_{S k-1}^{w}\right)^{2}\right]}{\rho_{o k-1}^{w} \rho_{o k}^{w}\left[\left(V_{P k-1}^{w}\right)^{2}-\frac{4}{3}\left(V_{S k-1}^{w}\right)^{2}\right]\left[\left(V_{P k}^{w}\right)^{2}-\frac{4}{3}\left(V_{S k}^{w}\right)^{2}\right]} ; k=\overline{n, 2} . \\
\beta_{n}^{g}=1 /\left[\rho_{o n}^{g}\left(V_{S n}^{w}\right)^{2}-4 / 3\left(V_{S n}^{g}\right)^{2} \rho_{o n}^{g}\right] .
\end{gathered}
$$

In the absence of the experimental values of $V_{S}$ from the data of $\mathrm{AL}$, such values are calculated by theoretical formulas and elastic parameters of rocks using the core research data. The values of compressibility of dry rocks in each layer are calculated taking into account the values of compressibility and share modulus of the adjacent layers (by formulas (Eq. (2)) and (Eq. (3))).

To calculate the values of compressibility in each of the conditional layers of a well section, as indicated above, using the parametric base data, the empirical relations of compressibility with porosity and pressure are constructed applying the least squares method (LSM). For the general parametric base of the WOGR (see Table 1), the linear relation of compressibility and porosity is determined in the first approximation. The effect of pressure is also determined (Fig. 2).

Here and below in correlation relations pressure $\mathrm{p}$ is measured in $\mathrm{MPa}$, porosity $\phi$ — in \%.

$$
\beta^{w}(\phi)=\beta_{0}(0.236 \phi+1.567), \beta^{w}(\partial)=\beta_{0}\left(4.94 p^{-0.114}\right) .
$$

However, since the effect of porosity and pressure on compressibility is complex and interdependent that is multiplicative (see below), then the optimized general empirical relation 

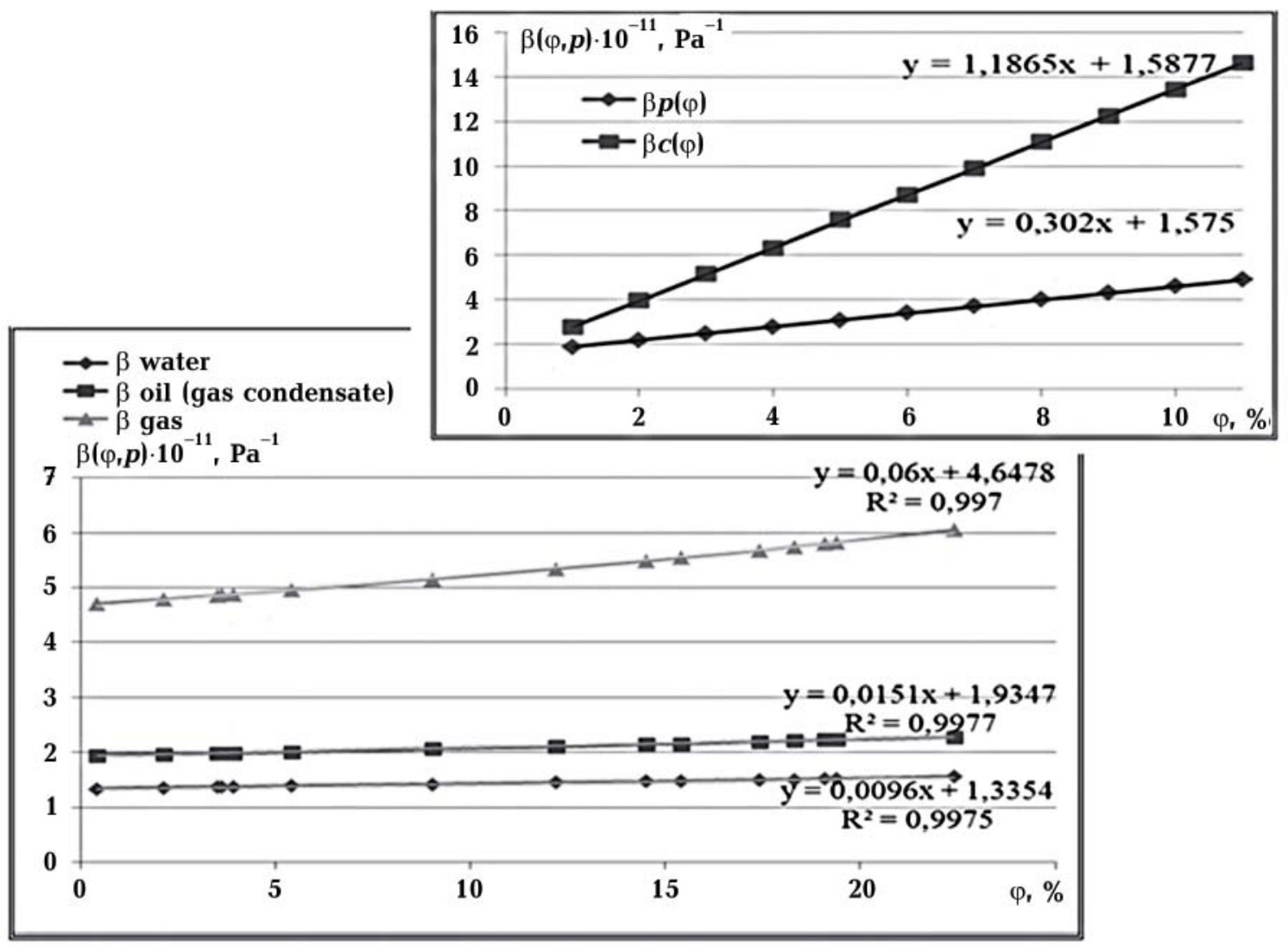

Fig. 3. Compressibility vs. porosity and the porous fluid type, developed from the averaged values of the velocity of longitudinal waves for collectors the WOGR (left bottom) and calculated from empirical relations for the parametric base of rocks the WOGR (right top).

of compressibility, porosity and pressure (Eq. (5)) is as follows:

$$
\beta^{g(w)}(p, \phi)=\beta_{0}\left(A+C p+D \phi p^{S}\right) .
$$

For the parametric base of the WOGR, the relation (11) for rocks with a liquid pore filler (see Table 1) is obtained by LSM

$$
\beta^{w}(\delta, \phi)=\beta_{0}\left(1.587-2.278 p 10^{-4}+0.301 p^{-0.197} \phi\right) .
$$

Distinguishing oil and water. The fluid in rock pores significantly influences the nature of propagation of elastic waves in rocks. The solution to the system of equations of the predictive technique (Eq. (1) - (5)) and the predictive functional (Eq. (7)) possess high sensitivity to a change of these elastic characteristics (Fig. 3). Therefore, our technique provides a reliable prediction of the type of a pore filler. This applies not only to the distinction between gas and liquid. The characteristics of the pore fillers - liquid and gas - varyconsiderably (Fig. 3, right top). The elastic characteristics of oil and water differ less (Fig. 3, left bottom). However, they are sufficient for their clear differentiation in conventional rock collectors.

In addition to the basic technique (according to functional (Eq. (7)), the distinction between oil and water in rock pores of wells is constructed in two variants - by the values of compressibility of rocks or the density of the pore filler. 
Distinguishing oil and water by compressibility of the fluid as a pore filler. Fig. 3 (left bottom) shows the results of calculating the compressibility by the formulas used in the technique for variously saturated rocks.

The calculation was made using the averaged values of the velocity of longitudinal waves for water-oil and gas-saturated rocks from the WOGR. To have a clear comparative picture of the behaviour of compressibility of variously saturated rocks, depending on their porosity, the calculated compressibility values for each type of the pore filler were extrapolated by using the linear relation and the corresponding graphs were constructed based on these expressions.

Similarly, plots of the compressibility behaviour are obtained depending on the porosity of rocks with a dry and liquid filler based on empirical relations (12) (Fig. 3, right top). It is clear that the difference between the compressibility values of variegated samples of rocks in all cases is expressive and sufficient for a clear diagnosis of the type of the pore filler in the layers of reservoir rocks under this parameter.

Table 2 demonstrates the differences between the values of compressibility predicted by the technique for various samples of sandstones and limestones.

\section{Ta b l e 2. Comparison of the values of compressibility for saturated by water, oil or gas samples of sandstones and limestones of the WOGR}

\begin{tabular}{|c|c|c|c|}
\hline $\begin{array}{c}\text { The sample of rock } \\
\phi=11 \% ; p=10 \mathrm{MPa} ; \rho_{T}=2630 \mathrm{~kg} / \mathrm{m}^{3}\end{array}$ & $\beta_{\text {water }} / \beta_{\text {oil }}$ & $\beta_{\text {water }} / \beta_{\text {gas }}$ & $\beta_{\text {oil }} / \beta_{\text {gas }}$ \\
\hline Clay limestone & 1.40 & 3.23 & 2.31 \\
Sandstone & 1.46 & 3.68 & 2.52 \\
\hline
\end{tabular}

Distinguishing oil and water by the density of the fluid as a pore filler. The density of reservoir water is known to be $1000-1150$ and even up to $1450 \mathrm{~kg} / \mathrm{m}^{3}$, due to impurities of salts; the density of oil/gas condensate in layer conditions reaches $600-850 \mathrm{~kg} / \mathrm{m}^{3}$. This makes it possible to distinguish between oil and water in the pores of rocks by determining the density of the fluid - the pore filler. We developed the method of distinguishing the type of the fluid according to its density based on the mathematical apparatus of the prediction technique.

A relation is used between the total volume density and the density of the rock mineral, its porosity and the density of the pore filler. It is expressed by the mean time equation (the Willy_-Gregory_-Gardner equation). From it the formula for determining the density of fluid $\rho^{w}$ is derived:

$$
\rho^{w}=\left[\left(\phi_{i}-1\right) \rho^{T}+\rho_{o}^{\prime}\right] / \phi,
$$

where $\phi$ - is a porosity of the $i$-th layer of the rock in the well, $\rho^{T}, \rho^{\prime}{ }_{o^{\prime}} \rho^{w}$, - are the density values, respectively, the solid component of the rock, the total bulk density, fluid density in pores - all for the $i$-th layer.

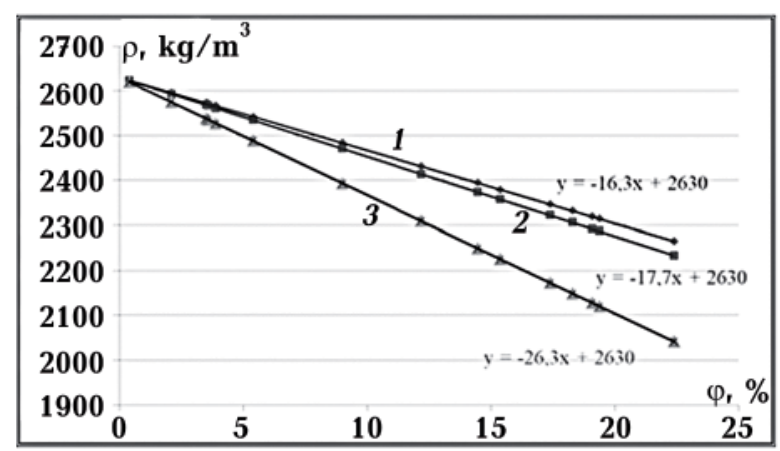

Fig. 4. Changes of average values of density for WOGR rocks with increase of porosity: 1 - the pores filler - water; 2 - oil/gas condensate; 3 - gas. 
On the other hand, the volume densities for each of the specimen of the rock of the $i$-th layer are calculated according to the experimental values of porosity and the values of densities of a liquid pore filler and a solid component of the rock. Based on them, the empirical relation of the volume density and porosity is developed to obtain such values of density $\left(\rho_{\text {tr }}\right)$ in the $i$-th layer. In addition, for calculations by the formula (Eq. (13)), density value $\rho^{\prime}{ }_{o}$ is obtained by taking into account geostatic and hydrostatic pressures.

The results of determining the type of a pore filler by density are illustrated by the example of the prediction of the fluid type for layers with water in depth intervals $182.4-182.8 \mathrm{~m}$ and 195.6-195.8 $\mathrm{m}$ in the section of the 3-Buchachska well (Table 3).

To determine the densities of the pore fillers, the volumetric densities of the rocks in these layers (the third column of Table 3) were used. Densities in the fifth column of Table 3 are calculated by the equation of the mean time. In accordance with the values of porosity in the layers, the density of the liquid pore filler was calculated: 968,963 and $962 \mathrm{~kg} / \mathrm{m}^{3}$ (the fourth column of Table 3$)$. For the average value of porosity ( $9.34 \%$ ), in the layers average value of the volume density of the rock is $2466 \mathrm{~kg} / \mathrm{m}^{3}$ and the density of the fluid is $964 \mathrm{~kg} / \mathrm{m}^{3}$. It indicates the pore filler of these rocks with a deviation of $3.6 \%$.

Ta b le 3. The results of the calculation of the volume density of rocks and the density of the predicted fluid-water in reservoir conditions for 3-Buchachs'ka well by the theoretical and empirical technique

\begin{tabular}{|c|c|c|c|c|c|}
\hline \multicolumn{3}{|c|}{$\begin{array}{c}\text { Calculation results from the theoretical and empirical technique } \\
\text { for layers with the pores filler - water }\left(\rho^{l}=1000 \mathrm{~kg} / \mathrm{m}^{3}\right)\end{array}$} & $\begin{array}{c}\text { Deviation of the calculated } \\
\text { value of the liquid density } \\
\text { from the experimental one }\end{array}$ \\
\hline and the density of the solid phase of the rock $\left(\rho^{T}=2682 \mathrm{~kg} / \mathrm{m}^{3}\right)$ & $\rho^{\text {stratum }} \mathrm{kg} / \mathrm{m}^{3}$ & $\rho^{w}, \mathrm{~kg} / \mathrm{m}^{3}$ & $\rho_{o^{\prime}} \mathrm{kg} / \mathrm{m}^{3}$ & $\rho^{l}-\rho^{\mathrm{w}}, \%$ \\
\hline 182.4 & 10.38 & 2503.5 & 968 & 2507.4 & 3.2 \\
182.6 & 8.63 & 2533.6 & 963 & 2450.5 & 3.7 \\
195.6 & 9.00 & 2527.2 & 962 & 2440.6 & 3.8 \\
\hline \multicolumn{6}{|c|}{ On the average: } \\
\hline
\end{tabular}

Fig. 4 demonstrates the results of the calculation of the volume density of rocks and the density of the predicted fluid-water in reservoir conditions obtained for the 3-Buchachska well from the theoretical and empirical technique.

Testing such a distinction by means of the predictive technique on other real data showed a deviation of the calculated fluid density from the actual one within the range of $3-8 \%$ (in average, $5.5-5.6 \%$ ).

Variants of the technique by using the data of other logs. For the cases of AL data lack for specific wells or sections intervals, variants of the theoretical and empirical technique are developed using the data of other logs and the development of appropriate correlation relations. These include, in particular, gamma-logging data, electric logging data and wave first inputs data by the offset method [Skakalska, Nazarevych, 2015a, 2016b].

Reliability of predicting the type of pore-fillers in the sections of wells on these variants of the technique is confirmed by matching the obtained values of porosity and the type of a pore filler in the corresponding intervals of sections with the results of industrial geophysics (see below).

The variant of the technique involving data of gamma-ray logging. Since gamma-logging does not give data directly related to the velocities of longitudinal waves, the known ratios were used to determine the clay content $\phi_{\mathrm{cl}}$ of clay layers and the coefficient of porosity by $\mathrm{AL}\left(\phi_{\mathrm{AL}}\right)$ [Skakalska, Nazarevych, 2016b]:

$$
\phi_{\mathrm{cl}}=\left(48.54 \Delta \mathrm{I}_{\gamma}+3.092\right) / 100, \phi_{(\mathrm{AL}+\mathrm{GL})}=\phi_{\mathrm{AL}}+0.204\left(\phi_{\mathrm{cl}}-0.07\right) \text { ， }
$$




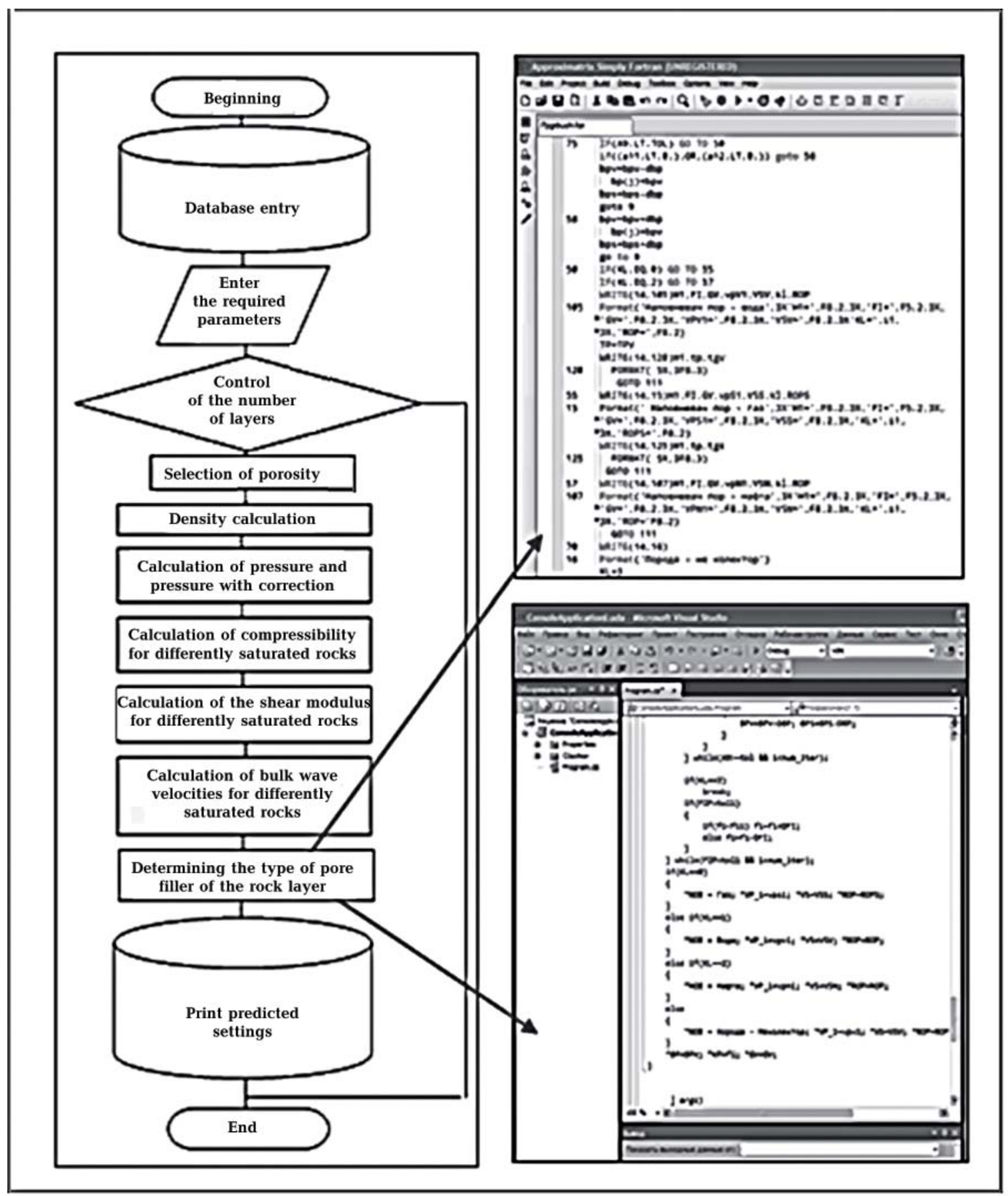

Fig. 5. The general algorithm of the predicting program (left) and fragments of programs for determining the type of the pores filler: "Predict-OGC-F» (in Fortran — right top) and «Predict-OGC-S» (in C\# — right below) [Skakalska et al., 2017].

as well as the equation of the mean time for porosity

$$
\phi_{\mathrm{AL}}=100\left(\Delta T_{l}-\Delta T_{\mathrm{AL}}\right) /\left(\Delta T_{l}-\Delta T_{w}\right) .
$$

Here $\Delta T_{1}$ - is interval time in the layer; $\Delta T_{\mathrm{AL}}$ - is interval time by $\mathrm{AL} ; \Delta T_{\mathrm{w}}$ - interval time in a porous fluid, which allowed us to take into account $I g$-intensity of gamma radiation in $\mathrm{mR} / \mathrm{h}$. The parameter is reduced to the dimensionless value by a division into unit intensity. 
The correlation relation is derived between the intensity of gamma radiation and the basic parameters of the technique:

- for porosity

$$
\phi^{\mathrm{AK}}=0,204\left(0,039-0,485 \Delta^{2}{ }_{\gamma}\right)\left(\frac{1+\Delta I_{\gamma}}{\Delta I_{\gamma}}\right) ;
$$

- for velocity of longitudinal waves

$$
V_{P}^{\mathrm{AK}}=\Delta I_{\gamma} /\left[\Delta T^{T} \Delta I_{\gamma}+0,00204\left(\Delta T^{l}-\Delta T^{T}\right)\left(0,039-, 485 \Delta I_{\gamma}\right)\left(1+\Delta I_{\gamma}\right)\right], i=\overline{1, n} .
$$

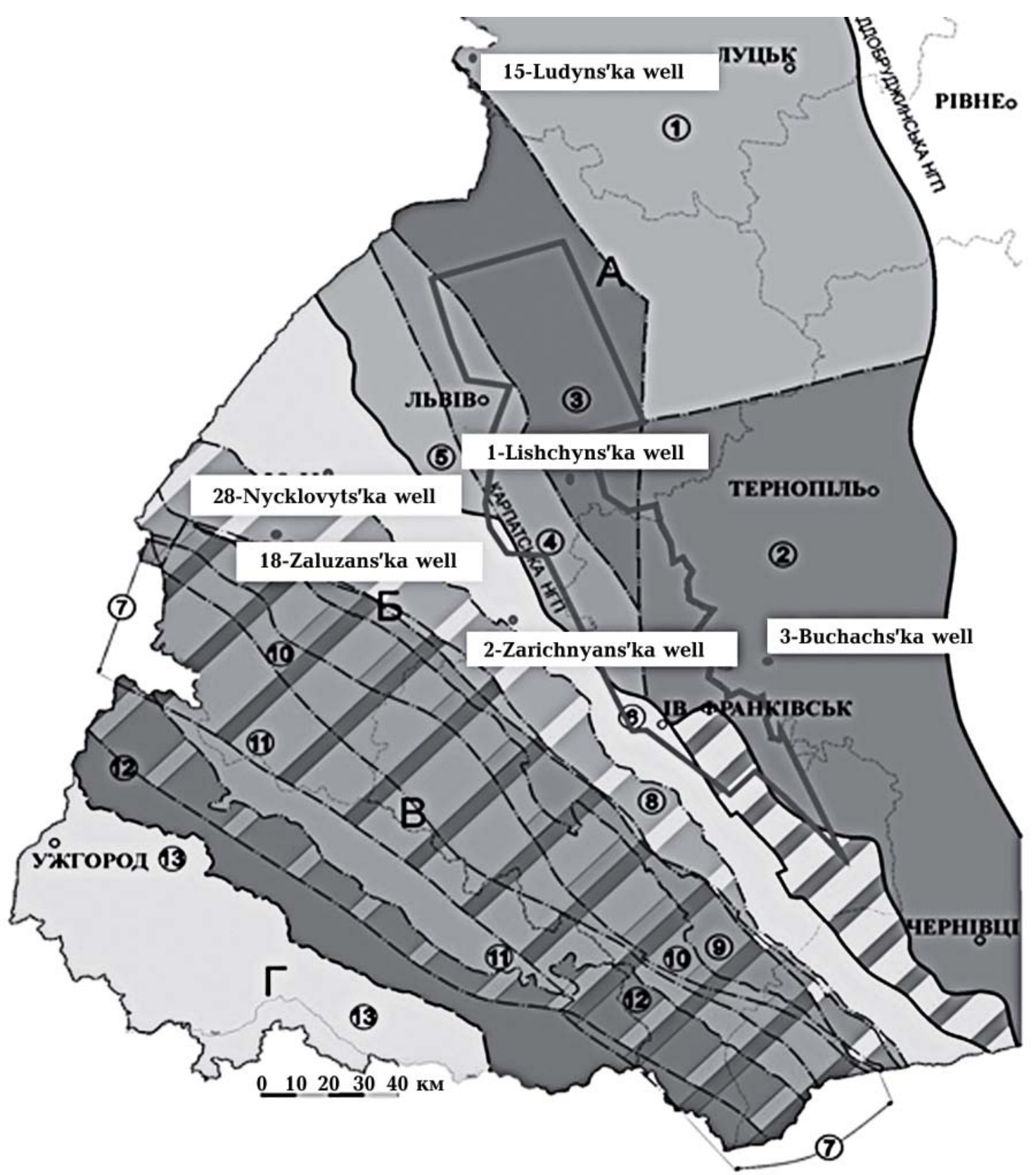

Fig. 6. Localization of the investigated wells on the schematic tectonic map of the Western oil-gas bearing region of Ukraine [Krups'kyy, 2001]. 
This variant of the technique is tested on the data of wells 3-Buchachs'ka, 15-Ludyns'ka, 4-North-Zarichnians'ka [Skakalska, Nazarevych, 2016b; Skakalska et al., 2017] (see below).

Research by IGGCAI the NASU

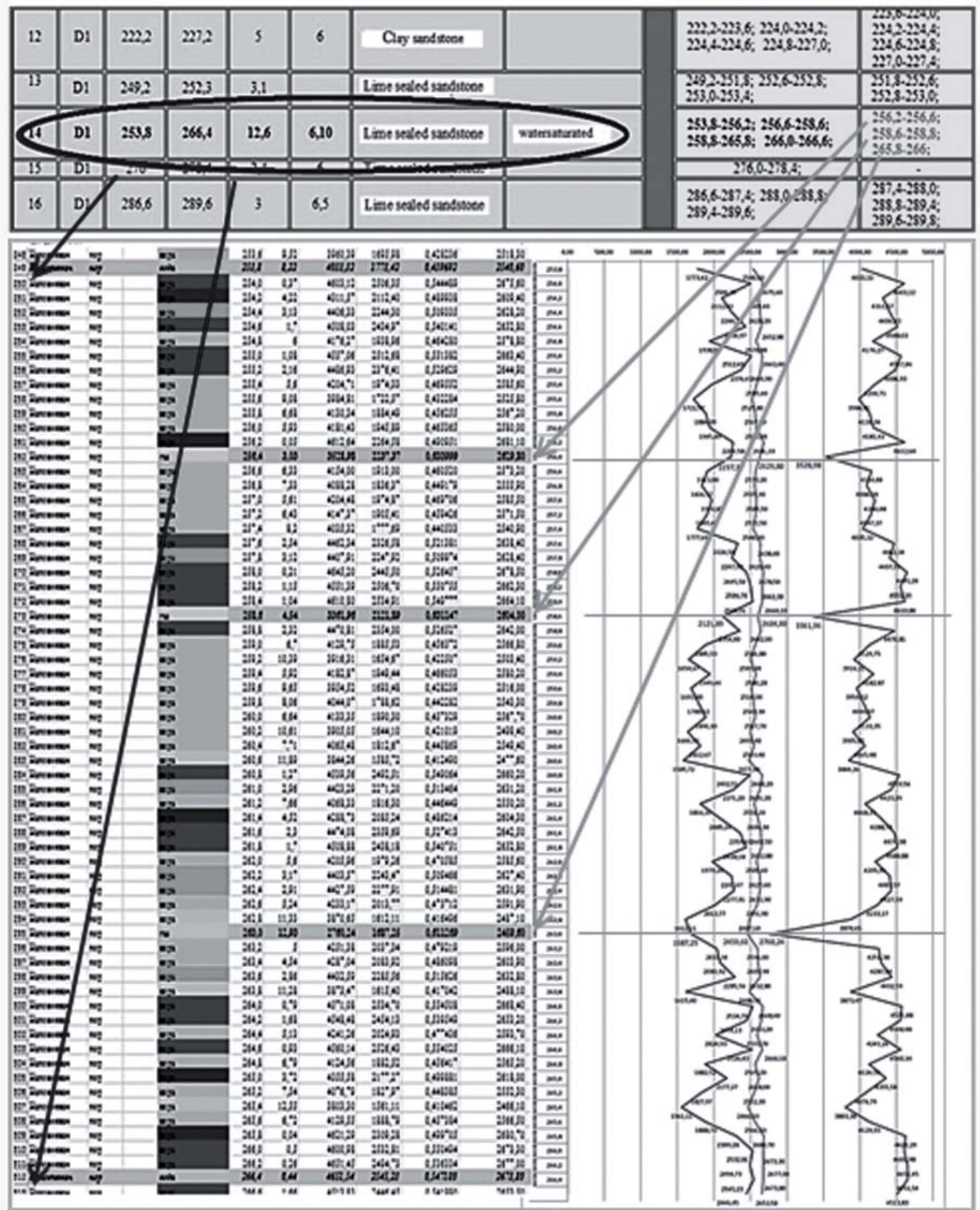

Fig. 7. The fragment of the results of an expanded and refined calculation of values of elastic parameters and the type of pore filler in the interval 253.8-266.4 m of 3-Buchachs'ka well section [Kurovets et al., 2012; Skakalska, Nazarevych, 2015a,b] from the predictive technique (blue — water, yellow - gas)

Research by methodics 
Variant of the technique involving data of electric logging (the method of self-polarization potentials). For the calculations, the expression is used for the relationship of parameter $\alpha_{\mathrm{ps}}$

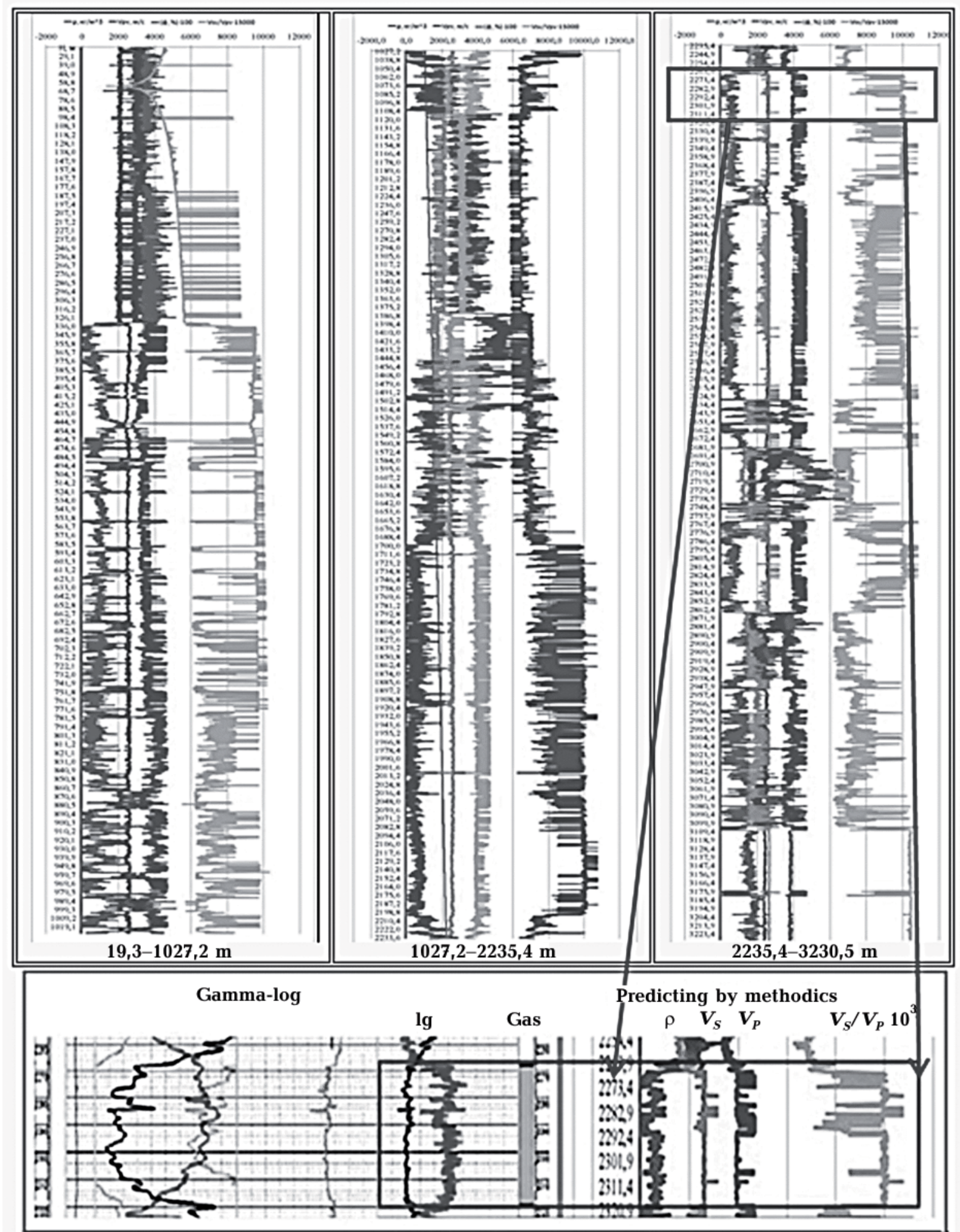

Fig. 8. The logging diagram of all section (on the top) and the interval 2263.9-2320.4 m (below) of the 15-Ludynska well (on the left) and prediction by the technique using gamma-log data [Kurovets et al., 2012; Skakalska, Nazarevych, 2015a,b] (on the right). 


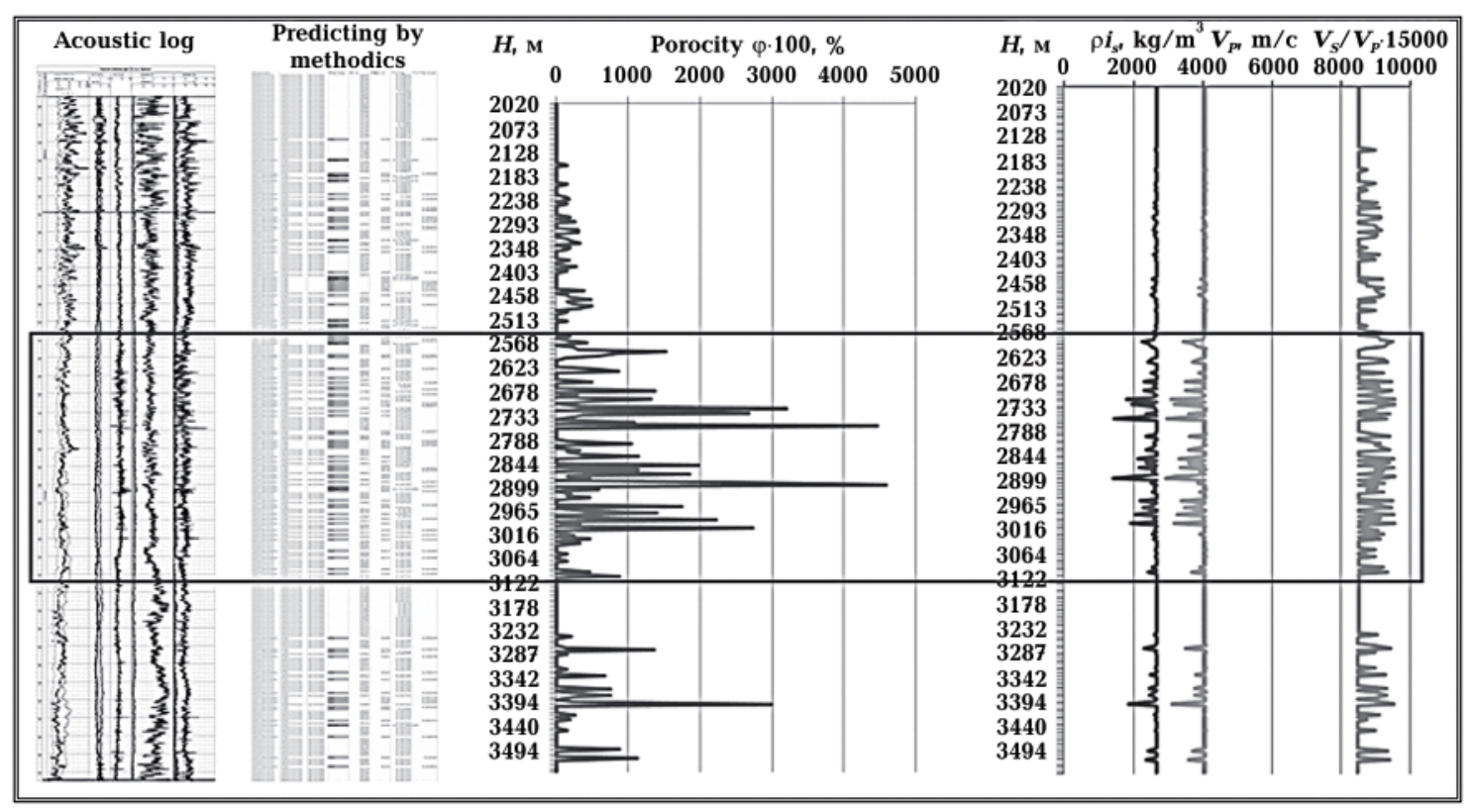

Fig. 9.The 1-Lishchyns'ka well. The column «Acoustic log» presents the results of industrial geophysics. In the column «Predicting by the technique», the colours indicate the type of the pores filler in each layer: gas — yellow, water - blue. The column "Porocity», " $V_{S)^{\prime}}$ " $V_{\left.P_{»}\right)^{\prime}}$ " $V_{S} / V_{P}$ » shows the change of these parameter values, according to the prediction by the technique [Skakalska, 2014a,b; Skakalska, Nazarevych, 2015b, 2016b].

with the porosity and clay content in the layer:

$$
\varphi_{\mathrm{AL}}=\varphi_{\mathrm{cl}}\left(2-a_{p s}\right) .
$$

Further, by the equation of the mean time for porosity, the velocity of longitudinal waves is determined. With the application of this variant of the technique, prediction for 2-Zarynchans'ka and 23-Orkhovyts'ka wells was successfully performed [Skakalska et al., 2017].

Program-methodical complexes. For the practical realization of the developed theoretical and empirical technique for hydrocarbons prediction in well sections and its variants, special calculation algorithms and the appropriate software packages are developed in Fortran environments («Predict-OGC-F») and C\# («Predict-OGC-C») [Skakalska et al., 2017] (Fig. 5).

The compilation is made of the Tables - databases, in particular, compressibility and share modulus for variously saturated rocks, including the velocity data of elastic waves in the Excel environment. In Excel empirical relationships are also developed for the prediction by the technique, the statistical analysis of the input data and the calculated values of different rock parameters and visualization of the calculation results (see below) [Skakalska, Nazarevych, 2014-2016; Skakalska et al., 2017].

\section{The results of the approbation of the technique}

Calculations were performed for Buchachs'ka, Lishchyns'ka and Ludyns'ka wells in prognostic productive structures and well-known hydrocarbon deposits of the Zaluzhans'ka, Zarichnyans'ki, Nyklovyts'ki, Orchovyts'ka oil and gas structures ofthe WOGR of Ukraine (Fig. 6) with characteristic types of rocks in sections (Fig. 7-9) using the predictive technique [Skakalska, 2014-2016; Skakalska, et al., 2017].

3-Buchachs' ka well. A depth of the 3-Buchachs'ka well is $4.4-2250.8 \mathrm{~m}$. It penetrated clay-carbonate rocks, densified with marl-limestone varieties. The prediction of elastic parameters, the coefficient of porosity, the pore filler (for layers of $0.2 \mathrm{~m}$ thickness) in the section of 


\begin{tabular}{||c|c||c|c||c|c||c||}
\hline Pore filler & $\boldsymbol{H}, \mathbf{m}$ & $\varphi_{\boldsymbol{r}} \%$ & $\boldsymbol{V}_{\boldsymbol{P}}$ & $\boldsymbol{V}_{\boldsymbol{S}}$ & $\boldsymbol{V}_{\boldsymbol{S}} / \boldsymbol{V}_{\boldsymbol{P}}$ & $\rho, \mathbf{K g} / \mathbf{m}^{3}$ \\
\hline \hline Gas & 639,50 & 17,85 & 2815,85 & 1745,77 & 0,61998 & 2342,9 \\
\hline \hline Gers & 641,00 & 13,88 & 3010,84 & 1892,2 & 0,02846 & 2411,3 \\
\hline Gas & 646,50 & 16,5 & 2881,91 & 1795,52 & 0,62303 & 2366,2 \\
\hline Gas & 650,00 & 15,66 & 2923,75 & 1827,04 & 0,62490 & 2380,6 \\
\hline \hline Gas & 654,00 & 15,55 & 2930,74 & 1832,39 & 0,62523 & 2382,5 \\
\hline
\end{tabular}

Indication of gas presence in the reservoir rock

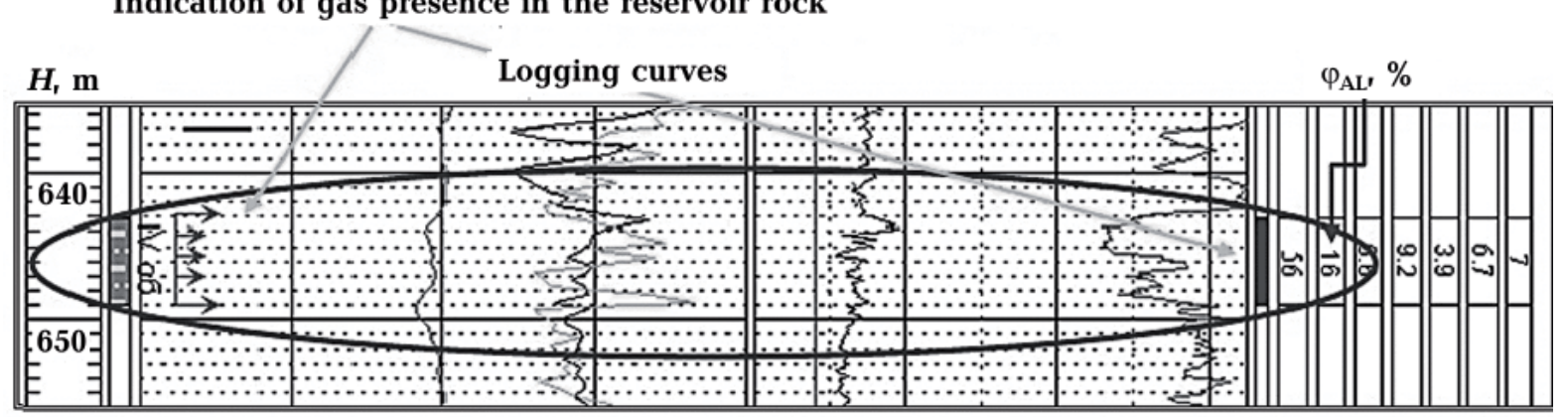

Fig. 10. The result of the prediction according to the technique for the interval $641-654 \mathrm{~m}$ in the 2-Zarichnians'ka well section and the corresponding fragment of the logging diagram (below) with the result of industrial tests (according to UkrSGRI, 2015).

this well in the basic version of the technique and gamma-logging [Skakalska, Nazarevych, 2015a,b] are in a good agreement with the data of industrial geophysics [Kurovets et al., 2012].

Fig. 7 shows a section fragment with a defined, mainly water-filled collector.

15-Ludyns' ka well. A depth of the 15-Ludyns'ka well is $19.3-3230.5 \mathrm{~m}$. It penetrated sandstones and carbonate-terrigenous rocks. Predicting is madeusing the technique of the gamma-logging data [Skakalska, Nazarevych, 2015a,b]. Figure 8 demonstrates a fragment of the results. The result of the industrial geophysics research (pink and grey in Fig. 8) and the results of the theoretical and empirical technique (green in Fig. 8) coincide (gas is predicted).

1-Lishchyns'ka well. A depth of the1-Lishchyns'ka well is 2020-3540 m. It penetrated Silurian organogenic Devonian carbon, argillites, siltstones and sandstones. The prediction is made by the basic variant of the technique (Fig. 9) [Skakalska, 2014a, b; Skakalska, Nazarevych, 2015b, 2016b]. A depth of the interval, the type of the pore filler (gas) and porosity are correctly calculated - the result of the theoretical and empirical technique coincides with those of industrial geophysics [Kurovets et al., 2012; Krups'kyy et al., 2014].

2-Zarichnyans'ka well. A depth of the 2-Zarichnyans'ka well is $0-865 \mathrm{~m}$. It penetrated increased clay alluvial deposits, which are cemented and composed of solid debris (conglomerates, gravelites and sandstones). Predicting is performed with the technique of the offset data and the gamma logging data. The results are consistent with the data of industrial geophysics (UkrSGRI, 2015) concerning the distribution of elastic wave velocities $\left(V_{S^{\prime}} V_{P}\right)$, density $(\rho), V_{S} / V_{P}$ parameter, the pore filler type and porosity $(\phi)$ (Fig. 10, the interval of the section with gas, $641-654 \mathrm{~m}$ ).

Statistical studies of petrophysical and reservoir characteristics of WOGR rocks. To improve the reliability of predictive estimates for the theoretical-empirical technique, empirical relations for a number of specific types and subtypes of reservoir rocks available in the sections of the corresponding wells were investigated and established in addition to statistical studies of relations for the general parametric base of the WOGR. For this purpose, the data were used for the compressibility of varieties of sandstones of WOGR for different depths/ 
pressures (the data are given by G. Petkevych), velocities of volumetric waves for sandstones of deep wells of the Precarpathian region (the data are from T. Verbytskyy) and for limestone species (the data are from I. Kurovets).

Statistical estimates for basic empirical relations. For the general parametric base of the WOGR, the results of the regression analysis were used to obtain estimates of standard deviations for coefficients of the formulas (10) between compressibility and porosity, compressibility and pressure, respectively:

$$
\begin{gathered}
\beta^{w}(\phi)=\beta_{0}((0.236 \pm 0.105) \phi+(1.567 \pm 0.170)), \\
\beta^{w}(p)=\beta_{0}(4.924 \pm 2.391) p^{-(0.095 \pm 0.051)} .
\end{gathered}
$$

\begin{tabular}{|c|c|c|c|c|c|c|c|c|c|c|c|c|c|}
\hline \multicolumn{14}{|c|}{$\beta_{t}=(1,578 \pm 0,11811) \cdot(0,003 \pm 0,00303) \cdot p+(0,302 \pm 0,01273) \cdot(p \cdot(0,198 \pm 0,00789)) \cdot \varphi$} \\
\hline$p=1 \mathrm{M \Pi а}$ & $\varphi=1 \%$ & & & \multicolumn{3}{|c|}{ The sum of the first two terms } & \multicolumn{3}{|c|}{ The third term } & \multicolumn{2}{|c|}{ Amount of terms } & \multirow{2}{*}{$\begin{array}{l}\beta_{t}(p, \varphi) \\
1,8770\end{array}$} & \multirow{2}{*}{\begin{tabular}{l|l}
\multicolumn{3}{l}{} \\
$\beta_{t}(p, \varphi)$ cep & 0,0000 \\
\end{tabular}} \\
\hline$\beta_{t}$ & & 1,5780 & 0,11811 & $1,1,5750$ & 0,003000 & 0,003030 & $0,30200,0127$ & 70,3020 & 0,1980 & 0,0079 & 1,8770 & & \\
\hline Max & + & 1,6961 & & 1,6901 & 0,006030 & & 0,3147 & 0,3147 & 0,1901 & & 2,0048 & 2,0048 & $\beta_{t}(p, \varphi)$ макс \\
\hline \multirow[t]{2}{*}{ Min } & - & 1,4599 & & 1,4599 & 0,000030 & & 0,2893 & 0,2893 & 0,2059 & & 1,7491 & 1,7491 & $\beta_{l}(p, \varphi)$ мін \\
\hline & $\Delta \beta_{t}=$ & 0,2362 & & 0,2302 & 0,006000 & & 0,0255 & 0,0255 & 0,0158 & & 0,2557 & 0,2557 & $\beta_{t}(p, \varphi)$ макс- $\beta_{\imath}(p, \varphi)$ мін \\
\hline$p=$ & 1 & \multicolumn{12}{|c|}{$\beta_{t}(p, \varphi)=(1,335 \pm 0,40344)+(0,244 \pm 0,2928) \cdot p+(1,187 \pm 0,5067) \cdot p-(0,278 \pm 0,0978) \cdot \varphi$} \\
\hline$\varphi=$ & 1 & & & \multicolumn{3}{|c|}{ The sum of the first two terms } & & \multicolumn{2}{|c|}{ The third term } & \multicolumn{2}{|c|}{ Amount of terms } & $\beta \beta_{t}(p, \varphi)$ & \\
\hline$\beta_{t}$ & & 1,3350 & 0,40344 & 1,5790 & 0,2440 & 0,2928 & $1,18700,5067$ & $7 \mid 1,1870$ & 0,2780 & 0,0978 & 2,7660 & 2,7660 & $\beta_{t}(p, \varphi)$ сер 0,0000 \\
\hline Max & + & 1,7384 & & 2,2752 & 0,5368 & & 1,6937 & 1,6937 & 0,1802 & & 3,9689 & 3,9689 & $\beta_{t}(p, \varphi)$ макс \\
\hline \multirow[t]{2}{*}{ Min } & - & 0,9316 & & 0,9804 & 0,0488 & & 0,6803 & 0,6803 & 0,3758 & & 1,6607 & 1,6607 & $\beta_{t}(p, \varphi)_{\text {мін }}$ \\
\hline & $\Delta \beta_{t}=$ & p,8069 & & 1,2949 & 0,4880 & & 1,0134 & 1,0134 & $|0,5560|$ & & 2,3083 & 2,3083 & $\beta_{t}(p, \varphi)$ макс- $\beta_{t}(p, \varphi)$ мін \\
\hline
\end{tabular}

Fig. 11. Calculation of multiplicative corrections for pressure and porosity for compressibility using empirical relations (20) and (21).

Similarly (with the estimates of standard deviations for the coefficients), general empirical relations are derived among pore compressibility, porosity, and pressure for rocks with both a liquid pore filler and dry:

$$
\begin{gathered}
\beta^{w}(p, \phi)=\beta_{0}\left((1.578 \pm 0.118)-(0.003 \pm 0.00303) p+(0.302 \pm 0.013) p^{-(0.198 \pm 0.008)} \phi\right) \\
\beta^{g}(p, \phi)=\beta_{0}\left((1.335 \pm 0.403)+(0.244 \pm 0.293) p+(1.187 \pm 0.507) p^{-(0.278 \pm 0.098)} \phi\right) .
\end{gathered}
$$

The obtained empirical relations (20) and (21) give almost the same compressibility value of the solid phase of rock at zero porosity $\left(\Delta \beta_{T}<0.4 \%\right)$, which confirms a good agreement among the empirical expressions of the connection of compressibility, porosity and pressure for dry and fluid-saturated rocks with the relevant characteristics. These and the above results justify the use of the derived relationships in the predictive technique.

A multiplicative component of the effect of pressure and porosity on compressibility. The study of statistical relations between elastic and reservoir parameters of rocks showed a complex interrelated (multiplicative) effect of porosity and pressure on their compressibility and elastic wave velocities. Therefore, the empirical relations in the form of (Eq. (11), (12), (20) and (21)) describe such effect much better than the sum of relations by (Eq. (10) and (19)). From the analysis of the obtained empirical relations (Eq. (20) and (21)), we see that the ten- 
sor parametric and nonlinear-elastic influence of porosity and pressure (the multiplicative component of pressure and porosity - the third term in formulas (Eq. (20) and (21))) is much stronger than the effect of pressure (the linear component, the second term). A pronounced difference is observed for rocks with a liquid fluid (Eq. (20)), where the compressibility of pores (due to filling them with a slightly compressible liquid pore filler) is much less. The multiplicative correction for pressure and porosity in compressibility calculations is determined from relationships (Eq. (20) and (21)) (Fig. 11).

For example, to determine a correction for porosity for each value of porosity, the value of compressibility is calculated by the formula (Eq. (20)) (see Table in Fig. 11, the third column to the right).

At zero porosity, the sum of the first two terms corresponds to compressibility of the solid phase of the rock sample under study. For other porosities, the difference between these values will be a correction for the particular value of porosity. The approximation curve obtained for such differences for a discrete number of porosity values gives an expression by which the correction value is calculated for each porosity. Determining and reducing the multiplicative correction for the both parameters $(p$ and $\phi)$ in predictive calculations, we obtain the compressibility value of the solid rock matrix and the possibility to determine the rock type in each layer of the well section using the known data from the previous laboratory studies without mining and the core studies of the particular well.

Specified empirical relationships for different types and subtypes of reservoirs. For the refined prediction of the oil and gas potential of section of specific wells with the known composition of rocks, it is advisable to use specified empirical relations developed especially for such rocks. To perform this, we obtained such relations according to G. Petkevich data (Table 4) for porous (Eq. (22)), compacted (Eq. (23)) and dense clay (Eq. (24)) of the WOGR' sandstones with estimates of the standard deviations of the corresponding coefficients for the degree of compressibility vs pressure

$$
\begin{aligned}
& \beta_{p}^{w}(p, \phi)=\beta_{0}\left((2.939 \pm 0.033)-(0.012 \pm 0.001) p+(0.272 \pm 0.004) p^{-(0.251 \pm 0.002)} \phi\right) \\
& \beta_{c}^{w}(p, \phi)=\beta_{0}\left((2.700 \pm 0.059)-(0.003 \pm 0.001) p+(0.252 \pm 0.007) p^{-(0.316 \pm 0.007)} \phi\right) \\
& \beta_{d}^{w}(p, \phi)=\beta_{0}\left((1.960 \pm 0.073)-(0.008 \pm 0.002) p+(0.216 \pm 0.016) p^{-(0.168 \pm 0.106)} \phi\right)
\end{aligned}
$$

Ta b le 4. Numerical estimates of the compressibility and porosity of sandstone samples

\begin{tabular}{|c|c|c|c|}
\hline \multirow{2}{*}{ Parameter } & \multicolumn{3}{|c|}{ Sandstone type } \\
\cline { 2 - 4 } & Porous & Compacted & Clay dense \\
\hline$\phi, \%$ & $8.7 \leq \phi \leq 23.1$ & $5.4 \leq \phi \leq 13.9$ & $3.3 \leq \phi \leq 9.1$ \\
$\beta=\beta_{0} \cdot 10^{11}, \mathrm{~Pa}^{-1}$ & $3.20 \leq \beta \leq 11,70$ & $2.80 \leq \beta \leq 7.6$ & $2,0 \leq \beta \leq 4.3$ \\
$\Delta \phi$ & 14.4 & 8.5 & 5.8 \\
$\Delta \beta$ & 8.50 & 4.80 & 2.30 \\
\hline \multicolumn{2}{|c|}{ Mean changes in compression with increasing porosity in sandstone subtypes } \\
\hline \multicolumn{2}{|c|}{$\mathbf{0 . 5 9}$} & $\mathbf{0 . 5 6}$ & $\mathbf{0 . 4 0}$ \\
\hline
\end{tabular}

Since our special studies have shown that the logarithmic dependence of compressibility on pressure has a better agreement with the real data than power equations, empirical formulas have been constructed in the form of a logarithmic dependences of compressibility on pressure for varieties of WOGR' sandstones. For example, for porous sandstones, we have: 


$$
\beta_{p}^{w}(p, \phi)=\beta_{0}(2.939 \pm 0,033)-(0.012 \pm 0.001) p+((0.295 \pm 0.002)-(0.053 \pm 0.03) \ln (p) \phi) .
$$

The extend of the improvement of the predictive result is estimated for each sandstone samples. For example, for porous sandstones, experimental compressibility values were selected for samples with the porosity $9.4,19.6,23.1 \%$. For them, compressibility calculations were performed with power and logarithmic dependences on pressure. Table 5 presents the obtained average relative deviations from the experimental values of compressibility.

Ta b le 5. The average relative deviations calculated for different approximation dependences of the compressibility values of $\beta$ on experimental values

\begin{tabular}{|c|c|c|c|c|}
\hline \multirow{2}{*}{$\phi, \%$} & \multicolumn{2}{|c|}{$\begin{array}{l}\text { The average relative deviations from the } \\
\text { experimental ones, } \%\end{array}$} & \multirow{2}{*}{$\Delta \beta(p)=\beta_{1}(p)-\beta_{2}(p)$} & \multirow{2}{*}{$\begin{array}{c}\quad \Delta \beta(p) / \beta(p)= \\
=\left(\beta_{1}(p)-\beta_{2}(p)\right) / \beta_{1}(p)\end{array}$} \\
\hline & $\beta_{1}(p)=D p^{\mathrm{L}}$ & $\beta_{2}(p)=K+T \ln (p)$ & & \\
\hline 9.4 & 6.75 & 3.57 & 3.18 & 0.47 \\
\hline 19.6 & 11.36 & 7.14 & 4.22 & 0.37 \\
\hline 23.1 & 12.7 & 8.34 & 4.36 & 0.34 \\
\hline
\end{tabular}

We observe a significant improvement of the compressibility calculation for these samples of porous sandstones (1.89; 1.59 and 1.52 times, respectively).

In general, the compressibility value obtained by logarithmic dependences for the range of porosity and pressure in the parametric base of various sandstones from the WOGR differs from the experimental ones by $3.5-8.5 \%$, which is on average 1.7 times better than by the dependences used earlier.

Conclusions. This paper presents a new theoretical and empirical technique for predicting the elastic characteristics and the oil, gas or water content of well sections according to acoustic logging data, as well as its variants by using data from other logs of the studied wells, by applying the compressibility parameter of rocks as the key parameter. The technique is effective for predicting elastic and collector characteristics of rocks of well section and for determining the type of the pores filler (oil-gas-water). We propose three ways of differentiation of the pore fillers: by the functional, by compressibility and by the density of the pore fluid.

The empirical relations are determined among compressibility, porosity and pressure of multi-saturated collector rocks for a number of specific characteristic types of collectors (porous, compacted and clay dense sandstones, etc.). The statistical estimates are obtained for the corresponding coefficients of such dependences. The study and determination of a multiplicative correction for pressure and porosity allows us to determine the type of rock in the well section without the core studies. The use of the logarithmic pressure dependence for this correction (and for empirical dependences in general) increases the accuracy of calculations by the factor of 1.7 compared with the power approximation used earlier.

For the well sections studied, a technique is developed for the detailed prediction of the fluid type and the corresponding set of petrophysical and collector rock characteristics. A positive feature of it is the ability predict effectively thin layers filled with hydrocarbons with shale crack ability.

\section{References}

Krups'kyy, Yu.Z. (2001). Geodynamicconditions of the formationand the oil-and-gas content in the Carpathian and Volyno-Podillyaregions of Ukraine. Kyiv: UkrSGP Publ., 144 p. (in Ukrainian).

Krups'kyy, Yu.Z., Kurovets', I.M., Sen`kovskyy, Yu.V., Mykhaylov, V.A., Chepil', P.M., Dryhant, D.M., 
Shlapins `kyy, V.Ye., Koltun, Yu.V., Chepil', P.M., Kurovets', S.S., \& Bodlak, V.P. (2014). Unconventional sourcesof hydrocarbons in Ukraine: Monograph. Book. 2. Western oil and gas region. Kyiv: Nicka Centre Publ., 400 p. (in Ukrainian).

Kurovets, I., Drygant, D., Naumko, I., Kurovets, S., \& Koltun, Yu. (2012). Geological and physicalchemical characteristics of lower Paleozoic deposits of Volyno-Podillya, Western Ukraine. Biuletyn Państwowego Instytutu Geologicznego, 449, 119-130 (in Polish).

Petkevych, G.I., \& Verbytskiy, T.Z. (1970). Acoustic studies of rocks in oil wells. Kiev: Naukova Dumka, 126 p. (in Russian).

Skakalska, L.V. (2014a). Physical and reservoir properties prediction for reservoir rocks in unconventional gas-bearing geological structures. Visnyk Taras Shevchenko National University of Kyiv. Geology, (1), 35-40 (in Ukrainian).

Skakalska, L.V. (2014b). Prediction of physical and reservoir properties of rock-reservoirs for searching of unconventional gas. SOCAR Proceedings, (1), 4-10. https://doi.org/10.5510/OGP20140100182. (in Russian).

Skakalska, L.V., \& Nazarevych, A.V. (2016a). Generalized equations for method of predicting of rocks oil-gas-water-saturation in the wells open-casts. Visnyk Taras Shevchenko National University of Kyiv. Geology, (1), 60-69 (in Ukrainian).

Skakalska, L.V., \& Nazarevych, A.V. (2015a). Predicting of fluid saturation of rock-collectors according to gamma-logging data: 14th EAGE International Conference on Geoinformatics - Theoretical and Applied Aspects «Geoinformatics-2015». Kyiv. https://doi.org/10.3997/2214-4609.201412364 (in Ukrainian).

Skakalska, L.V., \& Nazarevych, A.V. (2015b). Predicting of oil-gas-water-saturation of rocksof different lithology and geodynamic genesis in open-casts of wells. Geodynamics, (1), 102-119. https://doi. org/10.23939/jgd2015.01.099 (in Ukrainian).

Skakalska, L.V., \& Nazarevych, A.V. (2014). Techniques of predicting petrophysical characteristics of oil-gas-water-saturation of wells log (on the example of data of the 3-Buchachs'ka well, Ukraine). Interdisciplinary Institute «Science and education», (5), 25-29 (in Russian).

Skakalska, L.V., \& Nazarevych, A.V. (2016b). The methodology for predicting of oil-gas-saturation of rocks in open-casts of wells. Oil, Gas and Business, (3), 38-44 (in Russian).

Skakalska, L.V., \& Nazarevych, A.V., \& Kosarchyn, V.I. (2018). The theoretical-empirical technique of hydrocarbons prediction in the boreholes logs with the basic parameter - compressibility. Mineral resources of Ukraine, (4), 18-25 (in Ukrainian).

Skakalska, L.V., Nazarevych, A.V., \& Struk, Ye.S. (2017). Algorithms and programs for logging data processing in oil and gas predicting of rocks. Visnyk of NU «Lviv polytechnics» "Computer science and information technology», (864), 210-221 (in Ukrainian).

Verbytskiy, T.Z. (1977). The physical nature of the nonlinear elasticity of geological media with phase microinhomogeneities and the features of propagation of elastic waves in them. Geophysical collection of AN USSR, 75, 16-24 (in Russian).

Verbytskiy, T.Z., Pochynayko, R.S., Starodub, Yu.P., \& Fedoryshyn, A.S. (1985). Mathematical modelling in seismic prospecting. Kiev: Naukova Dumka, 276 p. (in Russian). 


\title{
Теоретико-эмпирическая методика прогнозирования углеводородов в разрезах скважин. Новые аспекты
}

\author{
А. Скакальская' ${ }^{1}$, А. Назаревич' ${ }^{1}$ В. Косарчин ${ }^{2}, 2021$ \\ ${ }^{1}$ Карпатское отделение Института геофизики им. С.И. Субботина НАН Украины, \\ Аьвов, Украина \\ ${ }^{2}$ Львовский национальный аграрный университет, Аьвов, Украина
}

Представлена разработанная теоретико-эмпирическая методика прогнозирования нефтегазоносности пород в разрезах скважин по данным акустического каротажа и керновых исследований (КИ) и ее варианты с использованием данных других каротажных методов, а также апробация ее для исследования геологических разрезов скважин Западного нефтегазоносного региона (ЗНГР) Украины. Математический аппарат созданной методики базируется на математической модели твердой пористой горной породы, эмпирических соотношениях между упругими и коллекторскими характеристиками горных пород и данных акустического каротажа по конкретным исследуемым скважинам. Ключевым в расчетах является параметр сжимаемости пород. Тип заполнителя пор породы (воды, нефти, газа) прогнозируется путем сравнения результатов расчета скоростей по теоретическим и эмпирическим зависимостям и фактических данных АК, по сжимаемости или по плотности флюида - заполнителя пор.

Разработаны дополнительные варианты методики на основе корреляционных зависимостей и данных других каротажных методов - гамма-каротажа, электрокаротажа, метода офсетов и сейсмокаротажа. Они используются в случае отсутствия данных АК для исследуемых скважин или отдельных интервалов их разрезов, а также для повышения надежности прогнозирования нефтегазоносности этих разрезов. Программное обеспечение Аля реализации методики разработано в средах Fortran, С\# и Excel.

Методика апробирована на данных скважин структур Западного нефтегазоносного региона Украины (Лищинской, Бучацкой, Аудинской, Залужанской, Заричнянской, Никловицкой). Методика обеспечивает надежное прогнозирование петрофизических характеристик, пористости и нефтегазоводонасыщенности пластов пород различной толщины (включая тонкие пласты — от 0,1-0,2 м) в разрезах скважин. Аля этого в дополнение к данным общей параметрической базы пород-колмекторов региона используются специально построенные по результатам анализа петрофизических характеристик различных конкретных типов и подтипов пород-коллекторов ЗНГР уточненные эмпирические соотношения для них.

Ключевые слова: теоретико-эмпирическая прогнозная методика; нефтегазоводонасыщенность пород; разрез скважины; акустический каротаж; керновые исследования; порода-коллектор; пористость; сжимаемость; корреляционные соотношения; Западный нефтегазоносный регион Украины. 


\title{
Теоретико-емпірична методика прогнозування вуглеводнів у розрізах свердловин. Нові аспекти
}

\author{
А. Скакальська ${ }^{1}$, А. Назаревич ${ }^{1}$, В. Косарчин ${ }^{2}, 2021$ \\ ${ }^{1}$ Карпатское відділення Інституту геофізики ім. С.І. Суботіна НАН України, \\ Аьвів, Україна \\ ${ }^{2}$ Львівський національний аграрний університет, Аьвів, Україна
}

Наведено розроблену теоретико-емпіричну методику прогнозування нафтогазоносності порід у розрізах свердловин за даними акустичного каротажу і кернових досліджень та їі варіанти з використанням даних інших каротажних методів, а також апробацію їі для дослідження геологічних розрізів свердловин Західного нафтогазоносного регіону України. Математичний апарат створеної методики базується на математичній моделі твердої пористої гірської породи, емпіричних співвідношеннях між пружними і колекторськими характеристиками гірських порід і даних акустичного каротажу по конкретних досліджуваних свердловинах. Ключовим у розрахунках є параметр стисливості порід. Пористість поріА і прогнозування типу заповнювача пор (води, нафти, газу) визначено шляхом порівняння результатів обчислення швидкостей за теоретичними та емпіричними залежностями з фактичними даними AK, за параметром стисливості порід, за густиною флюїду — заповнювача пор.

Розроблено додаткові варіанти методики на основі кореляційних залежностей і даних інших каротажних методів - гамма-каротажу, електрокаротажу, методу офсетів і сейсмокаротажу. Їх використано в разі відсутності даних АК для досліджуваних свердловин чи окремих інтервалів їх розрізів, а також дмя підвищення надійності прогнозування нафтогазоносності цих розрізів. Програмне забезпечення для реалізації методики розроблено в середовищах Fortran, C\# та Excel.

Методику апробовано на даних свердмовин структур Західного регіону України (Лiщинської, Бучацької, лудинської, Залужанської, Зарічнянської, Никловицької). Методика забезпечує надійне прогнозування петрофізичних характеристик, пористості і нафтогазоводонасиченості пластів порід різної товщини (зокрема тонких пластів - від $0,1-0,2$ м) у розрізах свердмовин. Аля цього як доповнення до даних загальної параметричної бази порід-колекторів регіону використано спеціально побудовані за результатами аналізу петрофізичних характеристик різних конкретних типів і підтипів поріА-колекторів уточнені емпіричні співвідношення дмя них.

Ключові слова: теоретико-емпірична прогнозна методика; нафтогазоводонасиченість порід; розріз свердловини; акустичний каротаж; кернові дослідження; порода-колектор; пористість; стисливість; кореляційні співвідношення; Західний нафтогазоносний регіон України. 